\title{
Análise do uso e cobertura da terra nas áreas de preservação permanen- te das nascentes da sub-bacia de Mato Grosso-Brasil
}

\author{
Land use/land cover analysis in the Permanent Preservation Areas at the springs of \\ the sub-basin from Mato Grosso State-Brazil
}

\author{
Jéssica Cocco, Edineia Aparecida dos Santos Galvanin, Higor Vendrame Ribeiro, Diego de \\ Lima Nascimento
}

Universidade do Estado de Mato Grosso, MG ,Brasil

jessicacocco.bio@gmail.com; galvaninbbg@unemat.br; higor.vendrame@gmail.com; diego.lnasc@gmail.com

\begin{abstract}
This study analyzed the land-use of Permanent Preservation Areas at the springs in the Sangue river sub-basin, Mato Grosso State, Brazil. LANDSAT-8 and RapidEye satellite images from 2014 was used. The clipping of the land use area from the springs was done to quantify land use in the Permanent Preservation Area. The results showed that Agriculture occupies the largest study area. Most Natural Forest is concentrated in the northern part of the Sangue river basin. Most Permanent Preservation Areas of springs in the sub-basin are in accordance with the Forest Code (Código Florestal). The other Areas are in conflict, regarding its use. The municipality of Nova Maringá presents the largest amount of Permanent Preservation Areas in accordance with the Forest Code (Código Florestal) and Campo Novo do Parecis the largest quantity in disagreement.
\end{abstract}

Keywords: Remote sensing; Land use; Geotechnology.

\section{Resumo}

O objetivo deste trabalho é analisar o uso e cobertura das Áreas de Preservação Permanente das nascentes na sub-bacia do rio do Sangue, Mato Grosso. Foram utilizadas imagens dos satélites Landsat-8 e RapidEye do ano de 2014. Foi realizado o recorte da área das nascentes para quantificação do uso da terra na Área de Preservação Permanente. Os resultados permitiram verificar que a agricultura ocupa a maior área de estudo. A maior parte da cobertura natural, a floresta, está concentrada na parte norte da bacia do rio do Sangue. As Áreas de Preservação Permanente das nascentes da sub-bacia do rio do Sangue encontram-se, em sua maioria, em acordo com o código florestal e as outras áreas estão em conflito de uso. O município de Nova Maringá apresenta a maior quantidade de Áreas de Preservação Permanente em acordo com o código florestal e Campo Novo do Parecis a maior quantidade de APPs em desacordo.

Palavras-chave: Sensoriamento Remoto; Uso da terra; Geotecnologias. 


\section{Introduction}

The hydrographic basin is a piece of land with a drainage system formed by a main river and its tributaries controlled in the geographical space by a watershed which drains the water coming from springs and rainfall, and of solid material to a common outlet that can be a stream, river, lake, reservoir or ocean (CARVALHO et al. 2012).

Among the components of the basin, the springs are outcrops of groundwater originating a water source that will accumulate natural ponds or streams, creeks, streams and rivers (BRASIL, 2012). Thus the springs mark the passage of the groundwater to the Earth surface (SILVA et al. 2012).

According to Santos, Nascimento and Arcos (2012) the springs are hydrological elements of primary importance for the river dynamics and the formation of rivers, because they have the necessary flow for the formation of the drainage network (CRISPIM and MALYSZ, 2012), since the water arising from rainfall, does not retain by itself the water flow. So if there is a disappearance of a spring, there will be a reduction of the stream, decreasing the volume of water in the hydrological region (CASTRO, 2007).

The springs are considered Permanent Preservation Areas (APPs), so it is necessary to preserve them in a $50 \mathrm{~m}$ radius surrounding each spring, according to the Federal Law n.o 12651 of May 25th 2012 establishing the Forest Code (Código Florestal) (BRASIL, 2012), and CONAMA Resolution n. 903 of March 20th 2002 (MINISTÉRIO DO MEIO AMBIENTE, 2002), indicating that the springs are places where any agricultural activity is forbidden, including livestock or any other activity that removes natural vegetation and causes an adverse impact to the environment.

However, the occupation of APP by agriculture and urban expansion is growing and has led to profound and rapid changes in these environments, increasingly affecting the areas of natural protection (FREITAS et al. 2013)

In this sense, this study analyzed the use and coverage of APPs the springs in the sub-basin of the Sangue river Mato Grosso. Because the Sangue river is located in the state of Mato Grosso, a region that undergoes intense transformation of the landscape caused by activities such as livestock, agriculture and mining (SILVA et al. 2012).

The Mato Grosso State holds major rivers, which contribute with water to the Paraguay, Amazon and Araguaia Tocantins river basins. Sangue river belongs to the Amazon basin and it is considered one of the main tributaries to the sub-basin of Rio Juruena (MATO GROSSO, 2010), belonging to the Amazon basin and with a very large potential for generating electricity (CNDP$\mathrm{CH}, 2014)$. According to the Ministry of Environment (MMA, 2006) however, there are few studies conducted in the watersheds of the Amazon region.

The Mato Grosso State suffered a major landscape modification, since the beginning of the colonization process to the present day. In this context, it is noteworthy that Man is the main environmental transformation agent in order to seek new ways and means of using space according to his interests. This dynamic reflects the degradation of the natural environment caused by various activities such as livestock, agriculture, urbanization, mining and road construction. These facts motivate increasingly the exploitation of natural resources, in search for a greater economic development, surpassing the boundaries of land use (PIRES et al. 2012).

Thus, it becomes essential to survey quickly and reliably, quantitative information of human activities and their relationship with the environment in the short, medium and long term (ORTIZ and FREITAS, 2005).

In this context the geo-technologies, remote sensing, GIS, GPS, allow an integrated environmental analysis, enabling to understand those issues related to the alteration of the natural environment in space (SANTOS et al. 2012). According to Pires, Izippato and Mirandola (2012), these technologies advance significantly the development of studies in various aspects of the geographical space, such as the development of planning and management actions, for instance.

The objective of this study is to analyze the land use/ land cover of the APPs at the springs of the Sangue river, in Mato Grosso State.

\section{Materials and Methods}

\section{Study area}

The Sangue river sub-basin (SBHRS) is located in NW Mato Grosso State, between the geographical coordinates of $12^{\circ} 50^{\prime} 00^{\prime \prime}$ and $14^{\circ} 30^{\prime} 00^{\prime \prime}$ south latitude and $58^{\circ} 10^{\prime} 00^{\prime \prime}$ and $59^{\circ} 00^{\prime} 00^{\prime \prime}$ west longitude, occupying an area of approximately $4148.30 \mathrm{~km} 2$ (Figure 1). The SBHRS comprises the municipalities of Brasnorte, Campo Novo do Parecis, Nova Maringá and Tangará da Serra.

This basin presents mainly two types of vegetation: Seasonal Forest and Savanna (Mato Grosso, 2010). The regional climate is Tropical, with a precipitation regime composed of a rainy season from October to March and a dry season from April to September. Yearly average temperature and rainfall are $24.4^{\circ} \mathrm{C}$ and $1.500 \mathrm{~mm}$ respectively (DALLACORT et al. 2010).

\section{Methodological procedures}

Initially a visit to the area under study was made in the dry season (August, 2013), for photographic records of the types of land use/land cover in the region (attached Figure 1) and to collect Ground Control Points (GCPs) to support the classification of satellite images.

Subsequently, the sub-basins of Sangue river were delimited using Digital Elevation Model (DEM) topo- 


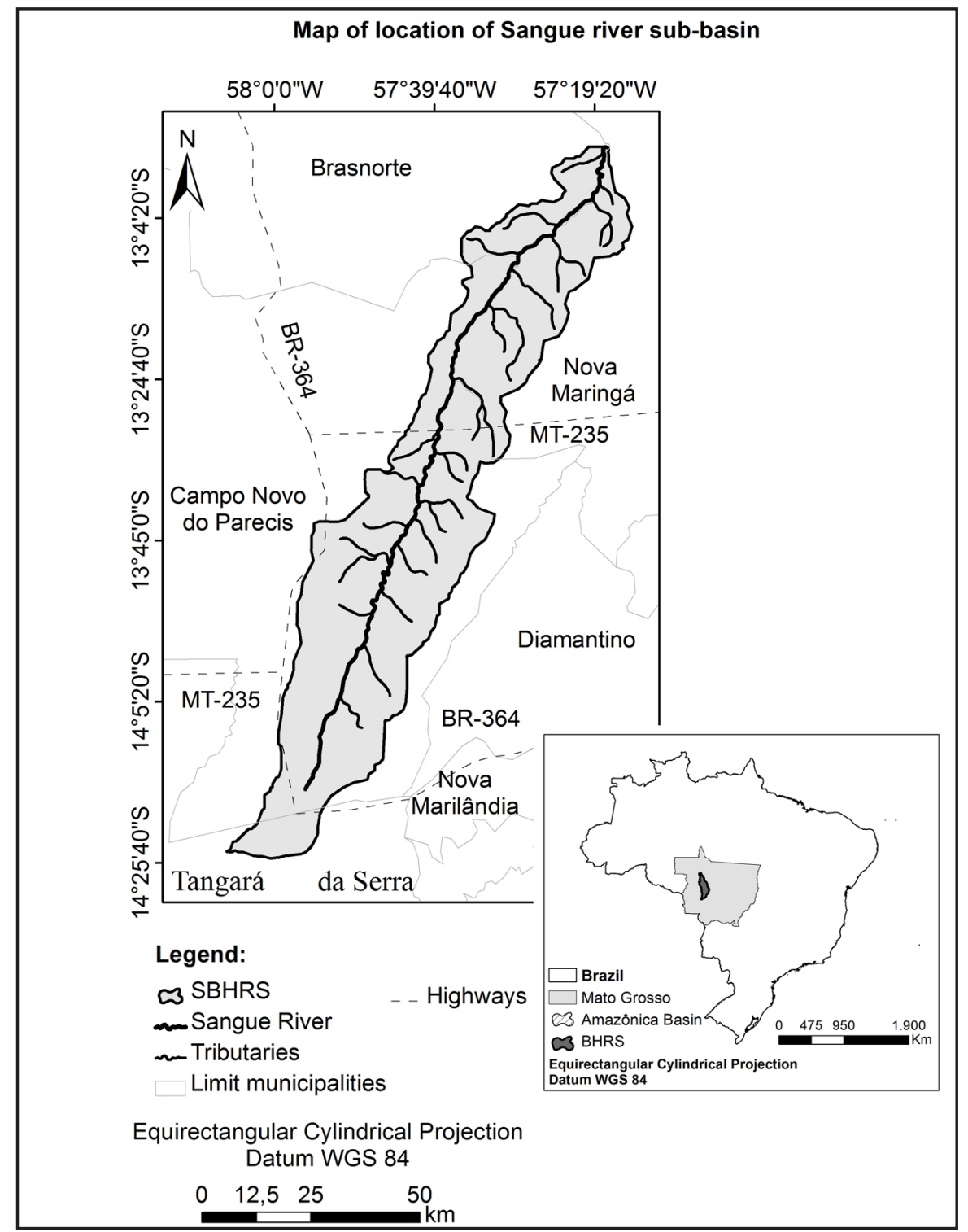

Figure 1 - Map of location of Sangue river sub-basin, Mato Grosso State, Brazil

graphy data from SRTM (Shuttle Radar Topography Mission) with a spatial resolution of 30m (BRUBACHERI et al. 2012) obtained at the TOPODATA Project database from Brazil, provided by INPE.

For the analysis of land use/land cover LANDSAT-8 images were acquired from Orbit / 228/70 and 69, Operational Land Imager (OLI), bands 6, 5, 4 (RGB) with 30 $\mathrm{m}$ spatial resolution, dated May 2014, available from the image catalogue of USGS (USGS, 2015).

Images were processed and analyzed using the SPRING software, version 4.1.8. (CAMARA et al. 1996). So a database was created using the UTM coordinate system, Datum WGS 84.

Afterwards a mosaic was made by import of a mask from SBHRS in shapefile. Mosaics were made by image segmentation using a region growth algorithm, grouping spectrally similar pixels, forming homogeneous regions. Tests were conducted with the similarity and area values that produced best results with similarity value 800 and area value 1200 , combining two spectrally similar regions in a single region and the best result in the individualization between regions, by the number of pixels (LORENZON et al. 2015).

In order to distinguish the classes of land use/land cover it was necessary to use the time series of the Enhanced Vegetation Index (EVI) provided by the Remote Sensing Laboratory for Agriculture and Forestry (LAF/ INPE), which enables to distinguish the different types of vegetation present in a given region (FREITAS et al. 2011; LOEBMANN et al. 2012; BISPO, 2013).

The land use classes were defined by image analysis and the methodology proposed in the Technical Manual for Land Use (IBGE, 2006) and the Technical Manual of the Brazilian Vegetation (IBGE, 2012). In this work six classes were considered, namely: Forest (all types of natural vegetation of the forest type), Savannas (all types of Savanna or Cerrado type), Agriculture (all types of perennial and temporary agriculture, pasture-agriculture- 
forestry system), water bodies (considering lakes, rivers, artificial lakes), pasture (all types of livestock: intensive, semi-intensive and extensive) and other athropogenic uses (including in this class urban areas, rural headquarters and engineering works such as power plants).

Following a supervised classification was made, with training (identification of samples from classes) of images from the dry season, using the region classifier Bhattacharrya with $99 \%$ acceptance (XAUD and EPIPHANIO, 2014)

At the end of the classification process, an accuracy evaluation was made using the Kappa index to verify the reliability of the map generated by SPRING. This index corresponds to the ratio between the sum of the main diagonal of the error matrix and the sum of all elements from this matrix, represented by the total number of samples, related to the total number of classes, considering the proportion of correctly classified samples (COHEN, 1960).

The maps generated at SPRING were transformed to thematic maps and afterwards in vectors and finally exported as shapefiles. The maps were processed with ArcGIS software, version 9.2 (ESRI, 2007) for the cartographic map edition and quantification of thematic classes, using the attribute calculator.

To execute mapping of the water sources, RapidEye satellite images were used, with a spatial resolution of 6.5 meters, provided by the Ministry of Environment. On the map with the springs the Buffer tool was applied, which is available in ArcGIS software, defining a radius of 50 meters, as required in the actual Brazilian Forest Code (Código Florestal) legislation, Law 12.651/2012 (Brasil, 2012) for the creation of APPs.

\section{Results}

Using the methodology applied in this work it was possible to generate the Table 1 presenting land use at SBHRS, showing land use classes for the year 2014 (Figure 2).

Table 1 - Land use/land cover classes in the SBHRS.

\begin{tabular}{c|c|c}
\hline \multirow{2}{*}{$\begin{array}{c}\text { Land use/land cover } \\
\text { classes }\end{array}$} & \multicolumn{2}{|c}{ Area of classes } \\
\cline { 2 - 3 } & ha & $\mathrm{km}^{2}$ \\
\hline Agriculture & $178.637,10$ & $1.786,37$ \\
\hline Water bodies & 181,8905 & 1,82 \\
\hline Forest & $137.218,04$ & $1.372,18$ \\
\hline Other human uses & $1.089,64$ & 10,90 \\
\hline Pasture & $27.302,36$ & 273,02 \\
\hline Savanna & $70.400,19$ & 704,0 \\
\hline Total & $414.829,30$ & $4.148,30$ \\
\hline
\end{tabular}

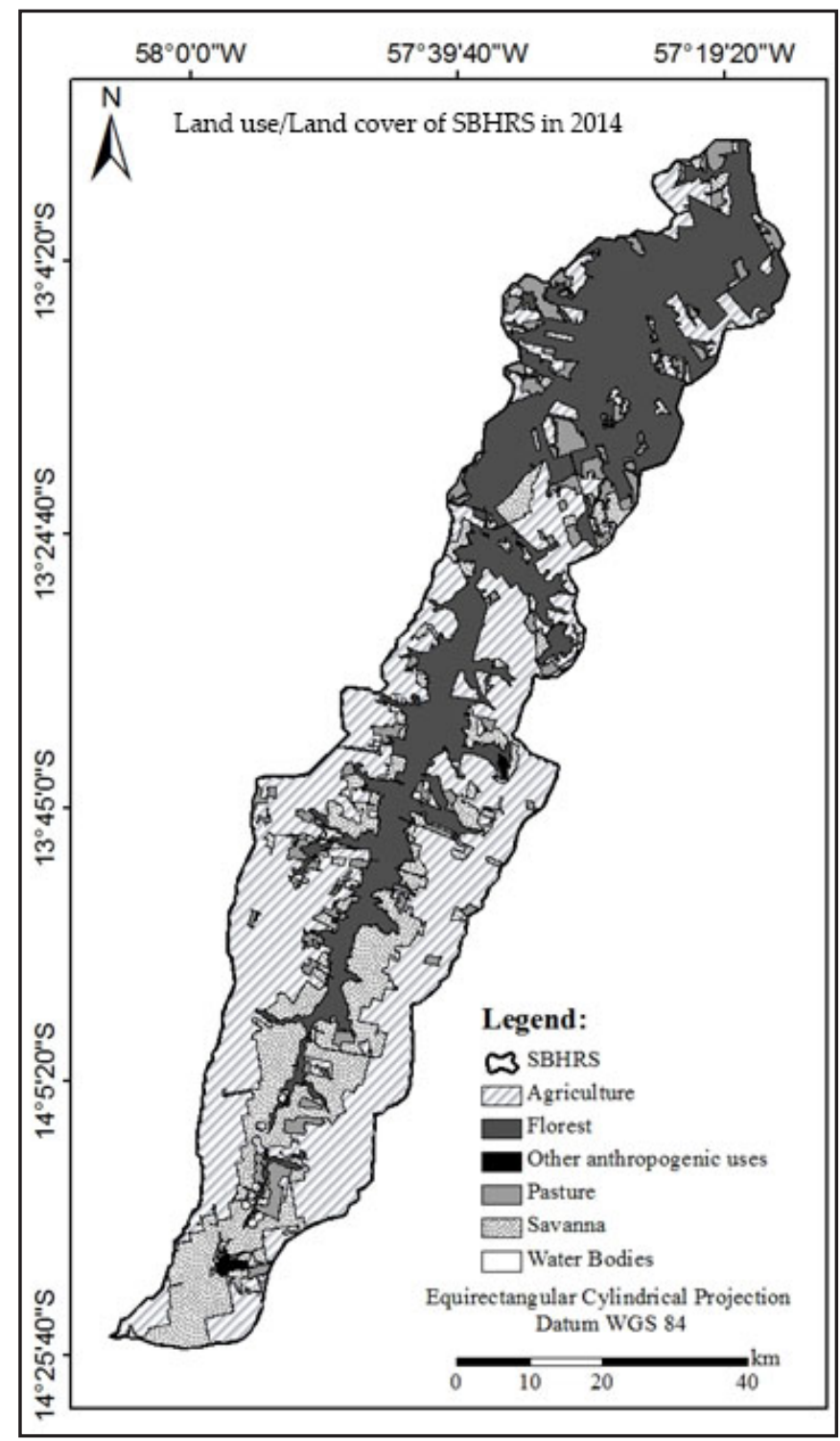

Figure 2 - Distribution of thematic land use/land cover classes at SBHRS in 2014

Agriculture is the main type of land use in SBHRS, occupying $43.06 \%$ of the area, located mainly in the south and extending marginally to the area of forest and savanna in the central part of the basin. The class other human uses occupy a smaller area of the sub-basin. This class is characterized by civil engineering works, such as the three hydroelectric power plants, Ixú, Garganta da Jararaca and Baruíto (Batista, Sánchez, Silva, Martinez \& Pasa, 2012), rural headquarters, warehouses among others, holding $0.26 \%$ of the sub-basin area. The pasture is located mainly in northern SBHRS, which occupied in $2014(6.58 \%)$ of the area from the sub-basin.

The natural vegetation cover is represented by forest classes, water bodies and savanna. Among these classes, forest covers the largest area in the sub-basin $(33.07 \%)$, mainly concentrated in the northern part. The class Savanna includes the Cerrado and Savanna cover, 
Table 2 - Types of land use/land cover at APPS from SBHRS, in 2014

\begin{tabular}{|c|c|c|c|c|c|c|c|}
\hline \multirow[b]{2}{*}{ Status of APPs } & \multirow[b]{2}{*}{$\begin{array}{c}\text { Type of land } \\
\text { use/land cover }\end{array}$} & \multirow[b]{2}{*}{$\begin{array}{l}\text { Amount } \\
\text { of APPs }\end{array}$} & \multirow[b]{2}{*}{$\begin{array}{l}\text { Area of } \\
\text { APPs } \\
(\%)\end{array}$} & \multirow[b]{2}{*}{$\begin{array}{l}\text { Area of } \\
\text { APPs } \\
\text { (ha) }\end{array}$} & \multicolumn{3}{|c|}{ Municipalities } \\
\hline & & & & & Brasnorte & $\begin{array}{c}\text { Campo Novo } \\
\text { do Parecis }\end{array}$ & Nova Maringá \\
\hline \multirow{3}{*}{$\begin{array}{c}\text { In accordance } \\
\text { with the Forest } \\
\text { Code }\end{array}$} & Forest & 75 & 46,30 & 58,75 & 12 & 24 & 39 \\
\hline & Savanna & 14 & 8,64 & 10,97 & --- & 13 & 1 \\
\hline & Forest + Savanna & 6 & 3,70 & 4,70 & 6 & --- & --- \\
\hline \multirow{7}{*}{$\begin{array}{l}\text { Conflict on } \\
\text { land use }\end{array}$} & Agriculture & 14 & 8,64 & 10,97 & 6 & 3 & 5 \\
\hline & Pasture & 6 & 3,70 & 4,70 & 2 & 2 & 2 \\
\hline & $\begin{array}{c}\text { Agriculture + } \\
\text { Forest }\end{array}$ & 26 & 16,05 & 20,37 & 6 & 13 & 7 \\
\hline & $\begin{array}{c}\text { Agriculture }+ \\
\text { Savanna }\end{array}$ & 2 & 1,23 & 1,57 & 2 & --- & --- \\
\hline & $\begin{array}{l}\text { Agriculture }+ \\
\text { Pasture }\end{array}$ & 4 & 2,47 & 3,13 & 1 & 2 & 1 \\
\hline & $\begin{array}{c}\text { Agriculture + } \\
\text { Forest + Savanna }\end{array}$ & 2 & 1,23 & 1,57 & 2 & --- & --- \\
\hline & Pasture + Forest & 13 & 8,02 & 10,18 & 1 & 6 & 6 \\
\hline \multicolumn{2}{|c|}{ Total } & 162 & 100 & 126,9 & --- & -- & --- \\
\hline
\end{tabular}

holding $16.97 \%$ of the area and is distributed in small sectors along the sub-basin. The class "Water bodies" presents the smallest area among the natural cover types $(0.04 \%)$ and it is constituted by natural and artificial lakes and rivers.

The land use/land cover map shown in Figure 2 was checked by the Kappa Accuracy Estimator, which showed a 0.997 index and overall accuracy of $99.86 \%$. In this map the spectral confusion occurred in the Savanna class: $0.89 \%$ of the pixels that should be attributed to this class were mistakenly given to class Agriculture.

Conflict and non-conflict data from Permanent Preservation Areas are presented on Table 2.

From the RapidEye satellite images, it was possible to verify 162 springs in SBHRS (Table 2). Among these, $58.64 \%$ are in APPs and in accordance with the Legislation. The most representative natural cover of these APPs was the Forest with $46.30 \%$. The other APPs, with $41.34 \%$, present land use conflict, and the main conflict of land uses were the combination of Agriculture and Forest (16.05\%), Agriculture (8.64\%) and Pasture and Forest (8.02\%) (Table 2).

At Figure 3 one observes that most of the springs closer to the main watercourse are kept conserved, i.e. without any kind of use, and the most distant sources of the main course present land use conflict.

Most of the APPs in accordance with the Forest Code (Código Florestal) are in municipalities Nova Maringá (40), followed by Campo Novo do Parecis (37) and Bras-

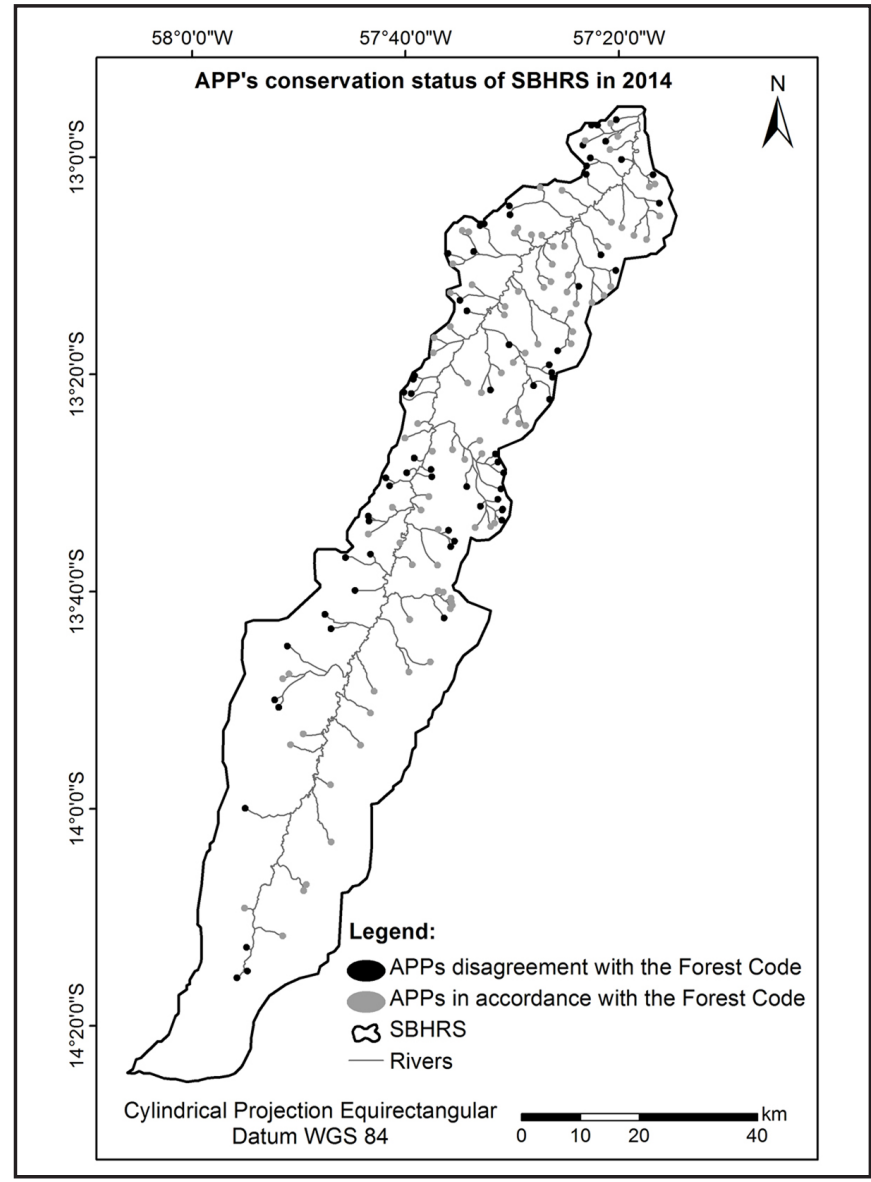

Figure 3 - Classification of water springs at SBHRS 
norte (18). Regarding the APPs with land use conflict, it was observed that 26 APPs are located in Campo Novo do Parecis, 21 in Nova Maringá and 20 in Brasnorte.

\section{Discussion}

The occupation of the natural environment along the historic process of colonization changed the landscape of the area under study. The sub-basin of Sangue river presents mainly Agriculture as the main form of land use, located in the southern region of the sub-basin and the forest is the main natural cover, located in the northern sub-basin.

These results corroborate with Oliveira-Junior et al. (2010) who highlight the variables Agriculture and Livestock as the main factors that contributed to the increase in deforestation of the Brazilian Amazon vegetation.

The process of deforestation in the Amazon, according to Arima et al. (2005) and Lapola et al. (2014), usually begins with the opening of roads, official or clandestine, that allow human expansion and illegal occupation of land for the irregular exploitation of hardwoods. Subsequently, the logged forest is converted into family farms and pastures for extensive livestock. Finally, pastures give way to mechanized agriculture (FERREIRAet al. 2005), mainly for soybean and cotton.

The agriculture, according to Costa et al. (2012), may allow an increase in income, quality of life and contribute to maintaining the population in rural areas. The economic gains brought by increased competitiveness of the agribusiness sector, which generates an increase in the production of the country.

However, the success of this sector has been associated with widespread destruction of Brazilian ecosystems, especially the Brazilian Amazon rainforest (MARTINELLI et al. 2010).

This model causes many problems to the environment, such as deforestation, increased risk of erosion and gradual loss of soil fertility, leading to the impoverishment of it, and consequently threatens the water resources of the region, promotes the siltation of rivers and there may be contamination by chemicals in fertilizers and pesticides often used in agriculture (OLIVEIRA-FILHO and LIMA, 2002; BALSAN, 2006; LOBATO et al. 2010).

The result of the land use/land cover map was checked by the Kappa Accuracy Estimator regarding its accuracy, which showed values considered as excellent $(\mathrm{K}>0.8)$ by Landis and Koch (1977), Fonseca (2000) and Manel et al. (2001), that is, that the classification is performed within the Earth reality. Demonstrating that based on the confusion matrix and the calculated accuracies, it can be said that Bhattacharrya was able to classify most regions properly.

The survey on RapidEye images allowed to identify 162 springs in the sub-basin of Sangue river, most of them in accordance with current legislation. The present forest cover in the springs indicates there is no any activity anthropic that removes the natural vegetation, and causes an adverse environmental impact (Ministério do Meio Ambiente, 2002).

All other APPs have land use mainly the combination between the classes agriculture and forestry. It shows that deforestation, aiming to improve the land use, to achieve high profitability, reached the extreme, leaving the springs devoid of riparian vegetation and exposed to various types of natural and anthropogenic agents.

It was found that most of the sources close to the main watercourse are conserved, that is with no use, whereas the most distant ones of the main course present conflicts of use.

Few studies have been conducted in the Amazon basin on the Permanent Preservation Area of the springs. Among the works in the literature we can highlight the study of Nobre et al. (2013) on the anthropogenic effects and its implications in the basin of Rio Carapá in Colíder, northern Mato Grosso State. The authors found that $60 \%$ of Permanent Preservation Areas are degraded. These areas present conflicts of use, mainly due to planted grass and degraded pasture.

These authors also emphasize that modifications without limits of the natural environment, combined with little information during the occupation period of the region, led to the degradation of water resources in the basin, showing that there was negligence by the State and violation of environmental laws by landowners.

In this context, Vaz and Orlando (2012) and Neves and Sousa (2013) state that the non-compliance with environmental legislation generates environmental impacts such as soil exposure to rain water, emergence of erosive processes, silting, pollution and water contamination, because the physical barrier made by riparian vegetation is often not present in sufficient quantities at some springs.

Nova Maringá municipality had the highest amount of APPs in accordance with the Forest Code (Código Florestal) and the Campo Novo do Parecis municipality the largest amount of APPs with land use conflicts. According to Oliveira-Junior et al. (2010) the municipalities of SBHRS are among the groups that have the largest areas of deforestation, Campo novo do Parecis is among the group of municipalities that deforested between $161,83 \mathrm{~km} 2$ and $673,73 \mathrm{~km} 2$ in four years (2000-2004), Brasnorte and Nova Maringá are the municipalities with a deforested area above $673,73 \mathrm{~km} 2$.

Carvalho et al. (2012) point out that it is necessary to conduct a proper management of the river basin, to preserve water resources and native forests, benefiting the wildlife movement and improving the quality of Permanent Preservation Areas as well as Legal Reserves, and consequently human life. In this sense Sparovek et al. (2012), points out that farmers look at the Brazilian Forest Law, the concept of conservation, as a barrier against the development. The concept of APPs, which 
is more directly related to water conservation, reduction of soil erosion and sediment flows in rivers, is perceived by farmers as a more acceptable restriction on their use of the land.

The preservation of a spring results in the maintenance of the water body, since each water body has a spring, thus the amount of water bodies will be the same amount of springs in a particular river basin (CRISPIM and MALYSZ, 2012; SERIGATTO, 2006). If there is a reduction of a spring it will result in the reduction in the number of water bodies, influencing the flow and overall water flow of the basin. Thus it appears that it is of fundamental importance to maintain the Permanent Preservation Area of the springs in order to ensure the environmental balance of the region.

It is essential that Government Action Plans are developed for the surveillance of deforestation in those areas destined to become APPs, as well as public policies to promote education and environmental management involving the livestock farmer, the producers, public managers and the society.

\section{Conclusion}

This study demonstrates the need for regular monitoring of the Sangue river sub-basin. Although the majority of APP's in the sub-basin are in accordance with Brazilian legislation (Forest Code) it is necessary to ensuring the maintenance of water rivers, the flow of matter and energy.

The other APP's, however, are in conflict of use, such as agriculture and pasture in the particular municipality of Campo Novo do Parecis. In this context, the use of APP's for productive purposes is very harmful to the ecosystem and the human population, revealing the need for community and government actions to promote information access for farmers on the importance of preserving the APP's.

In addition, this study demonstrates the need for a regular monitoring of the basin, based on the use of geo -processing techniques, which can instruct appropriately landowners about the laws in force to protect the natural vegetation and biodiversity.

\section{Acknowledgement}

This work was supported by the Coordination of Higher Education Personnel Training (CAPES).

\section{Reference}

RIMA, E. Y.; WALKER, R. T.; PERZ, S. G.; CALDAS, M. Loggers and forest fragmentation: Behavioral models of road building in the Amazon basin. Annals of the Association of American Geographers. 2005. 95(3). p. 525-541.
BALSAN R. Impactos decorrentes da modernização da agricultura brasileira. Revista de Geografia Agrária. 2006. 1(2). p. 123-151.

BATISTA, B. M. F.; SÁNCHEZ, D. C. M.; SILVA, J. V.; MARTINEZ, D. T.; PASA, M. C. Revisão dos impactos ambientais gerados na fase de instalação das usinas hidrelétricas: Uma análise da Sub-bacia do Alto JuruenaMT. Biodiversidade. 2012. 11(1). p. 69-85.

BISPO, R. C. Utilização de dados do sensor Modis no monitoramento e mapeamento da cultura de café. [Dissertação] Campinas-SP: UFC. 2013. 83p.

BRASIL. Lei nº. 12.651, de 25 de maio de 2012. Dispões sobre a proteção da vegetação nativa. Diário Oficial da União, Brasília (Brasil): Brasil. 2012.

BRUBACHERI, J. P.; OLIVEIRAI, G. G.; GUASSELLII, L. A.; LUERCE, T. D. Avaliação de bases SRTM para extração de variáveis morfométricas e de drenagem. Geociências. 2012. 31(3). p. 381-393.

CAMARA, G.; SOUZA, R. C. M.; FREITAS, U. M.; GARRIDO, J.; LI, F. M. SPRING: Integrating remote sensing and GIS by object-oriented data modelling. Computers \& Graphics. 1996. 20(1). p. 395-403.

CASTRO, P. S. Recuperação e conservação de nascentes. Viçosa: CPT. 2007. 272p.

CARVALHO, A. P. V.; BRUMATTI, D. V.; DIAS, H. C. T. Importância do manejo da bacia hidrográfica e da determinação de processos hidrológicos. Revista Brasileira de Agropecuária Sustentável. 2012. 2(2). p. 148-156.

Centro Nacional de Desenvolvimento de Pequenas Centrais Hidrelétricas - CNDPCH. Banco de Dados: Usinas em Operações. 2014. CNDPCH: Brasil.

COHEN, J. A. Coefficient of agreement for nominal scales. Educational and Psychological Measurement. 1960. 20(1). p. 37-46.

COSTA, C. C. D. M.; REIS, P. R. D. C.; FERREIRA, M. A. M. Impacts and externalities of agricultural modernization in Brazilian states. APSTRACT: Applied Studies in Agribusiness and Commerce. 2012. p. 53-61.

CRISPIM, J. Q.; MALYSZ, S.T. Conservação e proteção de nascentes por meio do solo cimento em pequenas propriedades agrícolas na bacia hidrográfica rio do Campo no município de Campo Mourão - PR. Revista Geonorte. 2012. 3(6). p. 781-790. 
DALLACORT, R.; MARTINS, J. A.; INOUE, M. H.; FREITAS, P. S. L.; KRAUSE, W. Aptidão agroclimática do pinhão manso na região de Tangará da Serra, MT. Revista Ciência Agronômica. 2010. 41(2). p. 373-379.

ESRI. ArcGIS Desktop: release 9.2. Redlands, CA: Environmental Systems Research Institute. 2007.

FERREIRA, L. V.; VENTICINQUE, E.; ALMEIDA, S. O desmatamento na Amazônia e a importância das áreas protegidas. Estudos Avançados. 2005. 19(1). p. 157-166.

FONSECA, L. M. G. Processamento digital de imagens. Instituto Nacional de Pesquisas Espaciais (INPE), São José dos Campos, São Paulo. 2000. 105p.

FREITAS, R. M.; ARAI, E.; ADAMI, M.; FERREIRA, A. S.; SATO, F. Y.; SHIMABUKURO, Y. E.; RUDORFF, B. F. T. Virtual laboratory of remote sensing time series: visualization of MODIS EVI2 data set over South America. Journal of Computational Interdisciplinary Sciences. 2011. 2(1). p. 57-68.

FREITAS, E. P.; MORAES, J. F.; PECHE FILHO, A.; STORINO, M. Indicadores ambientais para áreas de preservação permanente. Revista Brasileira de Engenharia Agrícola e Ambiental. 2013. 17(4). p. 443-449.

IBGE, Instituto Brasileiro de Geografia e Estatística. Manual técnico de uso da terra. Rio de Janeiro (Brasil): IBGE. 2006. 171p.

IBGE, Instituto Brasileiro de Geografia e Estatística. Manual técnico de vegetação brasileira. Rio de Janeiro (Brasil): IBGE. 2012. 271p.

LANDIS, J. R.; KOCH, G. G. The measurement of observer agreement for categorical data. Biometrics. 1977. 33(1). p. 159-174.

LAPOLA, D. M.; MARTINELLI, L. A.; PERES, C. A.; OMETTO, J. P. H. B.; FERREIRA, M. E.; NOBRE, C. A.; VIEIRA, I. C. G. Pervasive transition of the Brazilian landuse system. Nature climate change. 2014. 4(1). p. 27-35.

LOBATO, A. S.; CARVALHO, D. R.; SILVA, M. A.; ARAUJO, M. L.; BRITO, M. S. S. A formação do espaço mato-grossense: as transformações e impactos decorrentes da expansão da soja. In: ANAIS DO XVI ENCONTRO NACIONAL DOS GEÓGRAFOS [Internet]. Porto Alegre, Brasil. 2010.

LOEBMANN, D. G. S. W.; MAÇORANO, R. P.; SILVA, G. B. S.; VICENTE, L. E.; VICTORIA, D. C. Interpretação de alvos a partir de imagens de satélite de média resolução espacial. 21ํㅡㄹ Circular Técnica. Campinas: Embrapa Monitoramento por Satélite. 2012.
LORENZON, T. H.; PAIVA, S. L. P.; NEVES, S. M. A. S.; NEVES, R. J.; NUNES, E. S. Analysis of the conservation state from the permanent protection areas at the springheads and of the water from Cabaçal river drainage basin, Mato Grosso state, Brazil. Geografia. 2015. 40(40). p. 145-162.

MANEL, S.; WILLIAMS, H. C.; ORMEROD, S. J. Evaluating presence-absence models in ecology: the need to account for prevalence. Journal of Applied Ecology. 2001. 38(5). p. 921-931.

MARTINELLI, L. A.; NAYLOR, R.; VITOUSEK, P. M.; MOUTINHO, P. Agriculture in Brazil: impacts, costs, and opportunities for a sustainable future. Current Opinion in Environmental Sustainability. 2010. 2(5). p. 431-438.

MATO GROSSO, Secretaria de Estado do Meio Ambiente - SEMA. Relatório de Monitoramento da Qualidade da Água da Região Hidrográfica Amazônica - 2007 a 2009. Cuiabá (Brasil): Secretaria Estadual do Meio Ambiente. 2010.

MMA, Ministério do Meio Ambiente. Caderno da Região Hidrográfica Amazônica. Brasília (Brasil): Ministério do Meio Ambiente; 2006.

NEVES, P. D. M.; SOUSA, M. L. Caracterização geoambiental da Área de Preservação Permanente das nascentes do curso superior da bacia do Córrego Mandacaru do município de Maringá-PR: Aspectos Legais. Geo UERJ. 2013. 1(24). p. 386-406.

NOBRE, N. A. O.; ROQUE, C. G.; BAMPI, A. C. Efeitos antrópicos e suas implicações na bacia hidrográfica do rio Carapá, Colíder - Mato Grosso/Brasil. Revista de Geografia Acadêmica. 2013. 7(1). p. 70-80.

OLIVEIRA-FILHO, E. C.; LIMA, J. E. F. W. Impacto da agricultura sobre os recursos hídricos na região do cerrado. Planaltina: Embrapa Cerrados. 2002. 50p.

OLIVEIRA-JUNIOR, J. N. O.; DINIZ, M. B.; FERREIRA, R. T.; CASTELAR, I.; DINIZ, M. J. T. Análise da área desmatada municipal na Amazônia brasileira no período 2000-2004: Uma abordagem com modelos não lineares. Economia Aplicada. 2010. 14(3). p. 395-411.

ORTIZ, J. L.; FREITAS, M. I. C. Análise da transformação do uso da terra, vegetação e impactos ambientais por meio de sensoriamento remoto e geoprocessamento. Geociências. 2005. 24(1). p. 77-89.

SANTOS, W. L.; NASCIMENTO, F. I. C.; ARCOS, F. O. Uso da terra versus áreas de nascentes: Análise de impactos com utilização de geotecnologias no Sudoeste Amazônico -Acre - Brasil. Revista Geonorte, Edição Especial. 2012. 3(5). p. 1777-1787. 
SPAROVEK. G.; BERNDES, G.; BARRETTO, A. G. D. O. P.; KLUG, I. L. F. The revision of the Brazilian Forest Act: increased deforestation or a historic step towards balancing agricultural development and nature conservation? Environmental Science \& Policy. 2012. p. 65-72.

SERIGATTO, E. M. Delimitação automática de Áreas de Preservação Permanente e identificação dos conflitos de uso da terra na bacia hidrográfica do rio Sepotuba. [thesis]. Viçosa: Universidade Federal de Viçosa/UFV. 2006. 188p.

SILVA, R. A.; PIRES, E. V. R.; IZIPPATO, F. J.; MIRANDOLA, P. H. Geoprocessamento aplicado a análise do uso e ocupação da terra e APPs de nascentes no rio Indáia Grande - Chapadão do Sul/Cassilândia/ Inocência (MS). Revista Geonorte. 2012. 2(4). p. 1497-1508.

USGS, Geological Survey. Serviço de levantamento Geológico Americano. Aquisição de imagens orbitais digitais gratuitas do Satélite Landsat-8 [Internet]. [cited 2015 mar 20]. Available from: http://landsat.usgs.gov.

VAZ, L.; ORLANDO, P. H. K. Importância das matas ciliares para manutenção da qualidade das águas de nascentes: diagnóstico do Ribeirão Vai-Vem de IpameriGO. In: 21 ENCONTRO NACIONAL DE GEOGRAFIA AGRÁRIA. Uberlândia, Brasil. 2012.

XAUD, M. R.; EPIPHANIO, J. C. N. Dinâmica do uso e cobertura da terra no sudeste de Roraima utilizando técnicas de detecção de mudanças. Acta Amazônica. 2014. 44(1). p. 07-120. 